\section{A Treatment Combining Hot Water with Calcium Lactate Improves the Chilling Injury Tolerance of Mango Fruit}

\author{
Martha Edith López-López ${ }^{1}$, José Ángel López-Valenzuela ${ }^{1}$, \\ Francisco Delgado-Vargas, Gabriela López-Angulo, Armando \\ Carrillo-López, Lidia Elena Ayón-Reyna, and Misael Odín Vega-García ${ }^{2}$ \\ Facultad de Ciencias Químico Biológicas, Universidad Autónoma de Sinaloa, \\ $C d$. Universitaria, Av. de las Américas y Josefa Ortiz S/N, Culiacán 80010, \\ Sinaloa, México
}

Additional index words. mango, chilling injury, antioxidant enzymes, bioactive compounds, antioxidant capacity

\begin{abstract}
Keitt' mango is one of the most important cultivars, and it is usually stored at a low temperature during its commercialization to extend shelf life and reach distant markets. However, it is susceptible to chilling injury (CI) and some prestorage treatments are required to reduce the incidence of this disorder. This research shows for the first time the protective effect of a combination hot water-calcium lactate (Ca) against CI in mango fruit cv. Keitt. Fruit were subjected to hot water treatment (HWT) $\left(46.1^{\circ} \mathrm{C}, 75-90\right.$ minutes) or treated with $0.5 \% \mathrm{Ca}$ or with the combination HWT + Ca, stored at $5^{\circ} \mathrm{C}$ for 20 days, and ripened at $21{ }^{\circ} \mathrm{C}$ for 7 days. $\mathrm{CI}$ index (CII), electrolyte leakage (EL), malondialdehyde (MDA) production, bioactive compounds, antioxidant capacity $\left[2,2^{\prime}\right.$-azino-bis-3-ethylbenzthiazoline-6-sulphonic acid (ABTS) and 2,2diphenyl-1-picrylhydrazil (DPPH)], and activity of antioxidant enzymes [superoxide dismutase (SOD), catalase (CAT), and ascorbate peroxidase (APX)] were analyzed in mango samples after 0,10 , and 20 days of cold storage and after ripening. Hot water treatments (HWT and HWT $+\mathrm{Ca}$ ) were more effective than $\mathrm{Ca}$ in providing protection against CI as evidenced by lower incidence of symptoms and lower EL and MDA. HWT + Ca increased the content of phenolics, flavonoids, and carotenoids during the cold storage, which correlated with the antioxidant capacity by ABTS. SOD and APX showed higher activity in HWT + Ca-treated fruit, whereas CAT activity was higher in fruit with HWT and Ca. These results suggest that HWT + Ca provided CI tolerance of 'Keitt' mango by activation of the enzymatic and nonenzymatic antioxidant systems.
\end{abstract}

According to the international market of tropical fruits, the most important products are mango, pineapple, papaya, and avocado (FAO, 2010). In 2014, the global mango production was 45 million $\mathrm{t}$, and $3.87 \%$ of this production was from Mexico (FAOSTAT, 2017). Remarkably, Mexico is the largest mango exporter worldwide and produces the cv. Keitt, which is one of the preferred cultivars in the national and international markets (SAGARPA, 2017).

Mango is climacteric, harvested in physiological maturity, and shows high metabolic activity during postharvest. Consequently, fruit quality declines fast and the postharvest management conditions (e.g., pretreatments, storage, and transport) must be carefully selected (Ngamchuachit et al., 2014). Cold storage is

Received for publication 6 Oct. 2017. Accepted for publication 21 Nov. 2017.

We thank Blanca López, Denisse Diaz, Sady Pimienta, and Dennise Chairez for their dedicated technical assistance.

${ }^{1}$ These authors contributed equally to this article. ${ }^{2}$ Corresponding author. E-mail: mvega6@yahoo. com. commonly used to decrease the metabolic activity of climacteric fruits to increase their shelf life and to reach distant markets. However, mango develops a physiological disorder known as CI when it is stored at temperatures below 8 to $12{ }^{\circ} \mathrm{C}$, and it is more susceptible at physiological maturity (Yimyong et al., 2011). If the cold stress is for a long time span, the tissue is affected permanently damaging cell walls, membranes, and cellular compartmentalization, resulting in increased reactive oxygen species (ROS) production (Chidtragool et al., 2011). It has been demonstrated that visual CI symptoms appear after the fruit is removed from the cold storage and transferred to ripening conditions (Ding et al., 2007). The susceptibility to CI also depends on the genotype; preliminary studies showed that mango cv. Keitt was more susceptible to CI than other commercial cultivars in Mexico (Ataulfo, Haden, Kent, and Tommy Atkins) (data not published). The main CI symptoms in mango include uneven ripening, lenticel darkening, pitting, internal browning, off-flavor, and increased incidence to decay (Ketsa et al., 2000).

Fruit under abiotic stress increase the activity of their antioxidant enzymes (e.g.,
SOD, CAT, APX, and glutathione reductase) and the level of antioxidant compounds [e.g., phenolics, ascorbic acid (AA), carotenoids, tocopherols, and glutathione]. Both of them are related to the reduction of oxidative stress and the maintenance of the membrane integrity (Lopes et al., 2016; Wu et al., 2014; Zhao et al., 2006). Different procedures have been applied to reduce the CI of mango, including the treatment with calcium-arabic gum (Khaliq et al., 2015, 2016), hot air (Ketsa et al., 2000; McCollum et al., 1993), thermal shock (Zhao et al., 2006), and hot water (Almeida Miguel et al., 2016; Nyanjage et al., 1999; Talcott et al., 2005). Interestingly, the immersion of mangos in hot water $\left(46.1^{\circ} \mathrm{C}\right.$ ) for $65-110 \mathrm{~min}$ depending on the fruit size and weight is a mandatory quarantine treatment for pest control before exportation (USDA-APHIS, 2014). The hydrothermal treatment of mango reduces $\mathrm{CI}$, but it could decrease fruit firmness and increase the ripening rate (Almeida Miguel et al., 2016; Dea et al., 2010). On the other hand, the treatment of mango fruit with calcium salts improves their firmness, stress tolerance, and ripening. Calcium ions interact with fruit pectins forming calcium pectate that contributes to the cell wall stabilization, membrane integrity, and the maintenance of cell turgor and cell-to-cell contacts (Khaliq et al., 2015, 2016). Consequently, an adequate combination of treatments could improve the CI tolerance of mango. Thus, this research demonstrates for the first time the protective effect of the combination of the HWT and the Ca treatment $(\mathrm{HWT}+\mathrm{Ca})$ of mango against $\mathrm{CI}$; moreover, it reports the variations in the content of antioxidant compounds and the activities of antioxidant enzymes during cold storage and ripening of the fruit.

\section{Materials and Methods}

Mature-green mango fruit (Mangifera indica L. cv. Keitt) were obtained from a local producer in Culiacan, Sinaloa, Mexico. The fruit were selected based on the size $(400$ $600 \mathrm{~g}$ ), peel color uniformity, and absence of physical damage; then, they were washed with sodium hypochlorite $\left(300 \mu \mathrm{g} \cdot \mathrm{L}^{-1}\right)$ and divided into four groups (44 fruit/group). The treatments were the following: Control, $\operatorname{HWT}\left(46.1^{\circ} \mathrm{C}, 75\right.$ or $\left.90 \mathrm{~min}\right)$; calcium lactate treatment $(\mathrm{Ca}, 0.5 \% \mathrm{w} / \mathrm{v}, 75$ or $90 \mathrm{~min})$ (Manganaris et al., 2007; Silveira et al., 2011); and HWT + Ca (same conditions). All HWT were applied according to the USDA-APHIS (2014) standard that establishes the time of immersion in hot water $\left(46.1{ }^{\circ} \mathrm{C}\right)$ based on fruit weight $(75$ and $90 \mathrm{~min}$ for fruit of $375-500$ and $501-700 \mathrm{~g}$, respectively). The fruit was air-dried at $21^{\circ} \mathrm{C}$ for $1 \mathrm{~h}$ and stored at $5{ }^{\circ} \mathrm{C}$ for $20 \mathrm{~d}$ plus a ripening period of $7 \mathrm{~d}$ at $21^{\circ} \mathrm{C}$. The mango pulp of each fruit was homogenized, frozen with liquid nitrogen, and stored at $-70{ }^{\circ} \mathrm{C}$ until use.

CI index. The CII was determined according to Vega-García et al. (2010) with some modifications. A total of 80 fruit were evaluated, 
20 per treatment. The symptoms evaluated were lenticel darkening (L), pitting (P), uneven color development (U), and decay (D). The severity of the symptoms was measured visually as injury level (IL) using a 5-point scale based on the percentage of tissue affected for each criterion $(0=$ no tissue injury, $1=1 \%$ to $25 \%$ of tissue injury, $2=$ $26 \%$ to $50 \%$ tissue injury, $3=51 \%$ to $75 \%$ tissue injury, and $4=\geq 76 \%$ of tissue injury). The CII for each fruit was calculated by the following expression: $\mathrm{CII}=(\mathrm{ILL}+\mathrm{ILP}+\mathrm{ILU}$ + ILD) $/ 4$

Electrolyte leakage. The method described by Malacrida et al. (2006) was used with some modifications. For each treatment (four mangos), 18 mesocarp tissue cylinders ( $7 \mathrm{~mm}$ ) per fruit were cut with a cork borer. The cylinders were washed three times with deionized water to eliminate any electrolyte released during cutting. They were added with $25 \mathrm{~mL}$ of $0.4 \mathrm{M}$ mannitol solution and incubated at $25{ }^{\circ} \mathrm{C}$ for $2 \mathrm{~h}$ under constant shaking; the conductivity of the solution was measured using a manual conductivity meter (HI 98311; Hanna Instruments, Woonsocket, RI). After reading, samples were autoclaved at $121{ }^{\circ} \mathrm{C}$ for $10 \mathrm{~min}$ to release all the electrolytes. The samples were held at $25^{\circ} \mathrm{C}$ and the conductivity was measured again for total EL. The percentage of EL was determined as follows: $\% \mathrm{EL}=$ (initial electrolytes/total electrolytes) $\times 100$.

Malondialdehyde content. The MDA content was determined according to Hodges et al. (1999) by the thiobarbituric acid (TBA) technique. For each treatment (four mangos), $1 \mathrm{~g}$ of homogenized frozen tissue ( $3 \mathrm{~g}$ in total per fruit) was mixed with $30 \mathrm{~mL}$ of ethanol: water $(80: 20 \mathrm{v} / \mathrm{v})$ and centrifuged $\left(3000 g_{\mathrm{n}}, 4{ }^{\circ} \mathrm{C}\right.$ ) for $10 \mathrm{~min}$. One milliliter of supernatant was mixed with $1 \mathrm{~mL}$ of solution A (-TBA) containing 20\% trichloroacetic acid (TCA) $+0.01 \%$ butylated hydroxytoluene $(\mathrm{BHT})$ or solution B (+TBA) that contained $20 \%$ TCA $+0.01 \%$ BHT $+0.65 \%$ TBA. The solutions were shaken, heated $\left(95{ }^{\circ} \mathrm{C}, 25 \mathrm{~min}\right)$, and centrifuged. The absorbances were read at 440, 532, and $600 \mathrm{~nm}$ using an ultraviolet (UV)-vis spectrophotometer (Unico SQ2800; Unico Inc., San Diego, CA). MDA equivalents were calculated using the following formulas: 1$) A=\left[\left(\right.\right.$ Abs $\left.532_{+\mathrm{TBA}}\right)-$ (Abs 600+TBA) - (Abs 532-TBA - Abs $\left.\left.\left.600_{-\mathrm{TBA}}\right)\right], 2\right) \quad B=\left[\left(\mathrm{Abs} 440_{+\mathrm{TBA}}-\mathrm{Abs}\right.\right.$ $\left.\left.600_{+\mathrm{TBA}}\right) \times 0.0571\right]$, 3) MDA equivalents $\left(\mathrm{nmol} \cdot \mathrm{mL}^{-1}\right)=(A-B / 157,000) \times 10^{6}$.

\section{Analysis of Bioactive Compounds}

Preparation of methanol extracts (ME). Mango pulp was freeze-dried and $1 \mathrm{~g}$ was homogenized with $5 \mathrm{~mL}$ methanol, sonicated for $30 \mathrm{~min}$ at $30^{\circ} \mathrm{C}$, and allowed to stand for $24 \mathrm{~h}$ at $4{ }^{\circ} \mathrm{C}$. The procedure was carried out for $3 \mathrm{~d}$ exchanging the solvent every $24 \mathrm{~h}$. The recovered solvent was concentrated under vacuum to obtain the ME, which was stored at $-20{ }^{\circ} \mathrm{C}$ in darkness until its use.

Total phenolics (TP). Total phenolics content was determined as described by
Adom and Rui (2005) with some modifications. Forty microliters of the ME diluted in methanol $(1: 10 \mathrm{w} / \mathrm{v})$ were oxidized with 360 $\mu \mathrm{L}$ Folin-Ciocalteu reagent $(1: 8 \mathrm{v} / \mathrm{v})$ plus $100 \mu \mathrm{L} \mathrm{Na}{ }_{2} \mathrm{CO}_{3}(7 \% \mathrm{w} / \mathrm{v})$ for $90 \mathrm{~min}\left(21^{\circ} \mathrm{C}\right)$, and the absorbance was measured at $750 \mathrm{~nm}$. A standard curve was prepared using gallic acid (GA) $\left(50-600 \mu \mathrm{g} \cdot \mathrm{mL}^{-1}\right)$ and the results were expressed as milligrams of GA equivalents per $100 \mathrm{~g}$ of fresh weight [mg GAE/ $100 \mathrm{~g}$ fresh weight (FW)].

Total flavonoids. Total flavonoids were determined according to Moo-Huchin et al. (2014) with some modifications. The ME was diluted in methanol $(1: 3 \mathrm{w} / \mathrm{v})$ and $0.5 \mathrm{~mL}$ of this was mixed with $2 \mathrm{~mL}$ of deionized water and $150 \mu \mathrm{L}$ of $5 \% \mathrm{NaNO}_{2}$, allowed to stand for $5 \mathrm{~min}$, added with $150 \mu \mathrm{L}$ of $10 \% \mathrm{AlCl}_{3}$ in methanol, allowed to stand for $1 \min \left(25^{\circ} \mathrm{C}\right)$, and added with $1 \mathrm{~mL}$ of $1 \mathrm{~m} \mathrm{NaOH}$. Finally, the volume was adjusted to $5 \mathrm{~mL}$ with deionized water, shaken, and the absorbance was read at $415 \mathrm{~nm}$.

Ascorbic acid. AA concentration was determined according to Dürüst et al. (1997). Fresh mango pulp (1 g) was homogenized with $10 \mathrm{~mL}$ of $0.4 \%$ oxalic acid solution for $1 \mathrm{~min}$; an aliquot $(1 \mathrm{~mL})$ was mixed with $1 \mathrm{~mL}$ of acetate buffer ( $30 \mathrm{~g}$ sodium acetate anhydride $+70 \mathrm{~mL}$ water deionized $+100 \mathrm{~mL}$ glacial acetic acid) and $8 \mathrm{~mL}$ of 2,6dichlorophenolindophenol disodium salt (DCPI) solution $\left(12 \mathrm{mg} \cdot \mathrm{L}^{-1}\right)$ for $15 \mathrm{~s}$, and the absorbance was measured at $520 \mathrm{~nm}\left(L_{1}\right)$. For the second absorbance measurement $L_{2}$, the UV-vis equipment was adjusted to zero using the mixture that includes the sample, acetic buffer, and deionized water; $L_{2}$ corresponded to the absorbance of the mixture of sample with DCPI solution after $15 \mathrm{~s}$ of reaction. Thus, $L_{1}-L_{2}$ values represent the absorbance of the sample. The AA concentration was determined using a standard curve of AA (10-50 $\left.\mu \mathrm{g} \cdot \mathrm{mL}^{-1}\right)$ and the results were expressed as $\mathrm{mg}$ $\mathrm{AA} / 100 \mathrm{~g} \mathrm{FW}$.

Total carotenoids. The extraction and quantification of total carotenoids were carried out according to Moo-Huchin et al. (2014). Freeze-dried pulp (0.1 g) was homogenized with $5 \mathrm{~mL}$ of a solution containing hexane:acetone:ethanol (70:15:15 by volume) and $0.05 \%(\mathrm{v} / \mathrm{v})$ of BHT as antioxidant. The mixture was stirred for $1 \mathrm{~h}$ in darkness, saponified with $0.5 \mathrm{~mL}$ of $40 \%(\mathrm{w} / \mathrm{v}) \mathrm{KOH}$ in methanol for $2 \mathrm{~h}\left(25^{\circ} \mathrm{C}\right.$ darkness), added with $2 \mathrm{~mL}$ of hexane, vigorously shaken, and the upper layer was collected. The lower layer was extracted twice more, the three supernatants were mixed and filtered through anhydrous sodium sulfate powder. Total carotenoids content was determined by measuring the absorbance at $450 \mathrm{~nm}$. A calibration curve was prepared using pure $\beta$-carotene (BC) in hexane $\left(0-50 \mu \mathrm{g} \cdot \mathrm{mL}^{-1}\right)$ and the results were expressed as $\mathrm{mg} \mathrm{BC} / 100 \mathrm{~g} \mathrm{FW}$.

\section{Total Antioxidant Capacity}

ABTS method. This assay was performed as described by Re et al. (1999) with some modifications. The ABTS stock solution was prepared by mixing $5 \mathrm{~mL}$ of ABTS reagent (7 mM) with $88 \mu \mathrm{L}$ of potassium persulfate $(140 \mathrm{~mm})$ and kept in darkness at $25{ }^{\circ} \mathrm{C}$ for $12-16 \mathrm{~h}$. The ABTS solution was diluted with $7 \mathrm{~mm}$ phosphate buffer solution ( $\mathrm{pH}$ 7.4) to obtain an absorbance of $0.75 \pm 0.02$ at $734 \mathrm{~nm}$. In assay tubes, $10 \mu \mathrm{L}$ of ME diluted in methanol $(1: 7 \mathrm{w} / \mathrm{v})$ were mixed with $200 \mu \mathrm{L}$ of ABTS solution. The mixture was allowed to stand for $30 \mathrm{~min}$ at $27{ }^{\circ} \mathrm{C}$ in darkness and its absorbance was measured at $734 \mathrm{~nm}$ with a Microplate Reader (SynergyTM HT Multi-Detection; Biotek, Inc., Winooski, VT). Trolox (Sigma-Aldrich-238813, St. Louis, MO) was used to prepare a calibration curve $\left(0-225 \mu \mathrm{g} \cdot \mathrm{mL}^{-1}\right)$ and the antioxidant capacity was expressed as Trolox equivalents (TE) $(\mu \mathrm{mol} \mathrm{TE} / 100 \mathrm{~g} \mathrm{FW})$.

DPPH assay. The DPPH assay was carried out according to Brand-Williams et al. (1995) with minor modifications. ME was diluted in methanol $(1: 3 \mathrm{w} / \mathrm{v})$; an aliquot $(20 \mu \mathrm{L})$ was mixed with $180 \mu \mathrm{L}$ of $150 \mathrm{~mm}$ DPPH in methanol, incubated for $30 \mathrm{~min}$ $\left(27^{\circ} \mathrm{C} /\right.$ darkness $)$, and the absorbance was measured at $550 \mathrm{~nm}$. Results were reported as $\mu \mathrm{mol} \mathrm{TE} / 100 \mathrm{~g}$ FW.

\section{Activity of Antioxidant Enzymes}

Superoxide dismutase. SOD was determined according to Liu et al. (2005) with some modifications. Freeze-dried pulp $(0.5 \mathrm{~g})$ was homogenized in a cold mortar with $5 \mathrm{~mL}$ of ice-cold 0.05 M phosphate buffer ( $\mathrm{pH} 7.5$ ) containing $1 \mathrm{~mm}$ of ethylenediaminetetraacetic acid (EDTA) and 5\% of polyvinylpyrrolidone. The mixture was centrifuged $\left(17,200 g_{\mathrm{n}}, 4{ }^{\circ} \mathrm{C}\right)$ for $15 \mathrm{~min}$ and the supernatant was used to determine the enzymatic activity. The reaction mixture consisted of $1 \mu \mathrm{L}$ enzyme extract and $199 \mu \mathrm{L}$ of $0.1 \mathrm{M}$ phosphate buffer $(\mathrm{pH} 7.8)$ that contained $0.01 \mathrm{M}$ methionine, $0.025 \%$ Triton X-100, $0.11 \mathrm{~mm}$ EDTA, $57 \mu \mathrm{M}$ nitro blue tetrazolium chloride (NBT), and $50 \mu \mathrm{L}$ of $20 \mu \mathrm{M}$ riboflavin. The reaction was read in a microplate reader at $550 \mathrm{~nm}$ before and after light exposition $(25 \mathrm{~W})$ for $10 \mathrm{~min}$. One unit of SOD activity was defined as the amount of enzyme that would inhibit $50 \%$ of the photoreduction of NBT.

Catalase. Freeze-dried mango pulp ( $0.5 \mathrm{~g})$ was homogenized with $5 \mathrm{~mL}$ of extraction buffer containing $45 \mathrm{~mm}$ potassium phosphate buffer ( $\mathrm{pH} 7.0$ ), 5 mM of dithiothreitol, $5 \mathrm{~mm}$ EDTA, and $0.125 \mathrm{~g}$ of polyvinylpolypyrrolidone. The mixture was centrifuged $\left(17,200 g_{\mathrm{n}}, 4{ }^{\circ} \mathrm{C}\right)$ for $30 \mathrm{~min}$ and the supernatant was used to determine the enzymatic activity. The CAT activity was determined by measuring the disappearance of $\mathrm{H}_{2} \mathrm{O}_{2}$ for $5 \mathrm{~min}$ at $240 \mathrm{~nm}$, according to Yimyong et al. (2011) with some modifications. The reaction mixture contained $1 \mathrm{~mL}$ of phosphate buffer (40 mM, pH 7.0) $+\mathrm{H}_{2} \mathrm{O}_{2}(40 \mathrm{~mm})$ and $25 \mu \mathrm{L}$ enzymatic extract. The changes in $\mathrm{H}_{2} \mathrm{O}_{2}$ concentration were calculated based on its extinction coefficient $\left(43.6 \mathrm{M}^{-1} \cdot \mathrm{cm}^{-1}\right)$ at $240 \mathrm{~nm}$. CAT activity was expressed in units per milligram of protein. 
Ascorbate peroxidase. The APX activity was determined with the same extract used for evaluation of CAT activity and following the protocol of Yimyong et al. (2011) with some modifications. The reaction mixture contained $969 \mu \mathrm{L}$ of phosphate buffer (40 mM, pH 7.0), $5 \mu \mathrm{L}$ of AA (0.1 M), $1 \mu \mathrm{L}$ of $\mathrm{H}_{2} \mathrm{O}_{2}(0.1 \mathrm{M})$, and $25 \mu \mathrm{L}$ of enzymatic extract for a total reaction volume of $1 \mathrm{~mL}$. APX activity was expressed as units of activity per milligram of protein. The changes in AA concentration were calculated based on its extinction coefficient $\left(2.8 \mathrm{~mm}^{-1} \cdot \mathrm{cm}^{-1}\right)$ at $290 \mathrm{~nm}$.

Statistical analysis. Data were analyzed by two way analysis of variance; the factors were treatments (control, HWT, $\mathrm{Ca}$, and HWT $+\mathrm{Ca}$ ) and days of storage (with or without ripening). Significant differences $(P<0.05)$ between means were established using the least significant difference by Fisher's test. Pearson correlation coefficients $(r)$ were calculated between data sets $(P<$ $0.05)$. All analyses were performed using the software Statgraphics Plus 5.1 (Statistical Graphics, Rockville, MD).

\section{Results}

CI index. The storage of mango at $5{ }^{\circ} \mathrm{C}$ induced $\mathrm{CI}$ as registered by the increasing values of the $\mathrm{CII}$; the symptoms were better observed after the ripening period at $21{ }^{\circ} \mathrm{C}$. Remarkably, HWTs (HWT and HWT $+\mathrm{Ca}$ ) of mangos induced better protection against CI than Ca treatment (Fig. 1A) $(P<0.05)$. At the end of ripening after removal of cold storage, the CII for the HWT and HWT $+\mathrm{Ca}$ fruit were $42.8 \%$ and $30.4 \%$ lower than the corresponding control, but there were no significant $(P>0.05)$ differences between both treatments. The main CI symptoms in control- and Ca-treated mangos were lenticel darkening and pitting in the peel, as well as decay in peel and pulp (Fig. 1B), whereas HWT mangos only showed lenticel darkening and slight pitting in peel, reflecting the protective effect of HWT and HWT $+\mathrm{Ca}$ against CI.

Electrolyte leakage and MDA content. The EL values increased during the first $10 \mathrm{~d}$ of cold storage, especially in the control fruit that showed significantly $(P<0.05)$ higher values than the other treatments, which could be related with a protective effect provided to the fruit by the treatments (Fig. 2A). HWT + Ca was the best treatment showing the lowest EL values at the end of ripening after the removal of cold storage; the EL value of HWT + Ca mangos (57.21\%) was $1.30,1.09$, and 1.09 times lower than those of control-, HWT- and Ca-treated mangos, respectively, and showed significant differences $(P<0.05)$ with respect to the other treatments (Fig. 2A). On the other hand, the MDA content increased with the storage time at $5{ }^{\circ} \mathrm{C}$ and was higher after ripening $(P<0.05)$ (Fig. 2B). Analyzing the general patterns throughout the storage and ripening periods, both HWT and $\mathrm{Ca}$ treatments showed smaller MDA content than the control. At the end of ripening after the removal of cold storage, the Ca-treated fruit showed the lowest MDA values followed by HWT $+\mathrm{Ca}$ and HWT mangos $(P<0.05)$. During cold storage, HWT mangos were better protected than those with HWT $+\mathrm{Ca}$. However, the combination HWT + Ca was always better for mangos cold stored and ripened.

Bioactive compounds. Total phenolics values in control, HWT, and Ca-treated fruit decreased during cold storage, whereas an increase in the content of these compounds was observed in HWT + Ca fruit $(P<0.05)$ (Table 1). HWT + Ca mangos showed the highest TP (61.92 mg GAE/100 g FW) after $20 \mathrm{~d}$ at $5{ }^{\circ} \mathrm{C}(P<0.05)$. The ripening period increased the TP in all treatments except at the end of storage where HWT + Ca showed a reduction; TP contents were higher in HWT mangos (54.20-71.41 mg GAE/100 g FW) than control and HWT $+\mathrm{Ca}$ fruit $(P<0.05)$.

The total flavonoids content of mango stored at $5{ }^{\circ} \mathrm{C}$ decreased in the control and HWT fruit $(P<0.05)$ and increased in the Catreated fruit (Table 1). After $20 \mathrm{~d}$ of cold storage, HWT $+\mathrm{Ca}-$ and Ca-treated fruit showed about the same content of flavonoids (68.30 and $68.53 \mathrm{mg}$ quercetin equivalents (QE)/100 g FW, respectively). Ripening of Ca-treated mango improved their total flavonoids reaching the highest values (67.07 and $70.85 \mathrm{mg} \mathrm{QE} / 100 \mathrm{~g} \mathrm{FW}$ ) after 0 and $20 \mathrm{~d}$ of cold storage, respectively. On the other hand, fruit with the HWT + Ca treatment showed the lowest total flavonoids content $(60.02 \mathrm{mg}$ $\mathrm{QE} / 100 \mathrm{~g} \mathrm{FW}$ ) after $20 \mathrm{~d}$ of cold storage and $7 \mathrm{~d}$ of ripening.

Clear tendencies were not observed in the changes of the AA content of mango fruit stored at $5{ }^{\circ} \mathrm{C}$ for different periods (Table 1). The HWT fruit showed the highest values (16.44-19.58 mg AA/100 g FW), whereas the lowest values $(8.27-16.14 \mathrm{mg} \mathrm{AA} / 100 \mathrm{~g}$ FW) were observed in the HWT + Ca fruit. Ripening after the removal of cold storage decreased the AA content in all treatments. In general, the control fruit were the least affected (7.43-7.91 mg AA/100 g FW) and the HWT fruit were the most affected (6.05$9.53 \mathrm{mg} \mathrm{AA} / 100 \mathrm{~g} \mathrm{FW})$. At the end of the cold storage time and ripening, all-treated mangos showed similar AA contents $(P>0.05)$ with values ranging from $5.87 \mathrm{mg}(\mathrm{HWT}+\mathrm{Ca})$ to $7.43 \mathrm{mg} \mathrm{AA} / 100 \mathrm{~g} \mathrm{FW}$ (control).

Storage time at $5{ }^{\circ} \mathrm{C}$ affected the total carotenoid content of mango, showing a general increase during the first $10 \mathrm{~d}$ and then a decrease after $20 \mathrm{~d}$, with significant differences among treatments $(P<0.05)$ (Table 1); the lowest carotenoid contents were observed in the control fruit (7.15$8.93 \mathrm{mg} \mathrm{BC} / 100 \mathrm{~g} \mathrm{FW} ; P<0.05)$. After $20 \mathrm{~d}$ of cold storage, Ca-treated mangos showed the highest value (11.21 mg BC/100 g FW) followed by HWT $+\mathrm{Ca}(10.96 \mathrm{mg} \mathrm{BC} / 100 \mathrm{~g}$ FW). In mangos without cold storage $(0 \mathrm{~d})$, ripening increased $(P<0.05)$ the carotenoid content in all treatments, especially in the HWT fruit (12.83 mg BC/100 g FW). Considering the storage time, the carotenoid content of control, HWT, and HWT $+\mathrm{Ca}-$ treated fruit decreased but that of Ca-treated
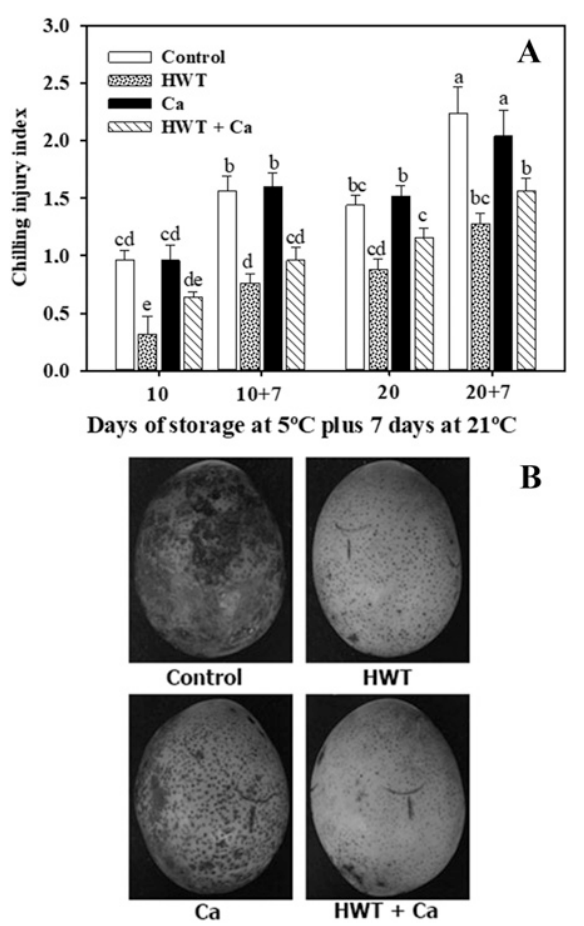

B

Fig. 1. Chilling injury $(\mathrm{CI})$ index in mango $\mathrm{cv}$. Keitt after 10 and $20 \mathrm{~d}$ of storage at $5{ }^{\circ} \mathrm{C}+7 \mathrm{~d}$ at $21^{\circ} \mathrm{C}$ (A). Symptoms of CI at the end of storage ( $20 \mathrm{~d}$ at $5{ }^{\circ} \mathrm{C}+7 \mathrm{~d}$ at $\left.21^{\circ} \mathrm{C}\right)(\mathbf{B})$. Data are the mean of five replicates with SD as vertical bars. Different letters show significant differences among treatments $(P<0.05)$ based on the least significant differences $(\mathrm{LSD}=0.36)$ by Fisher's test.

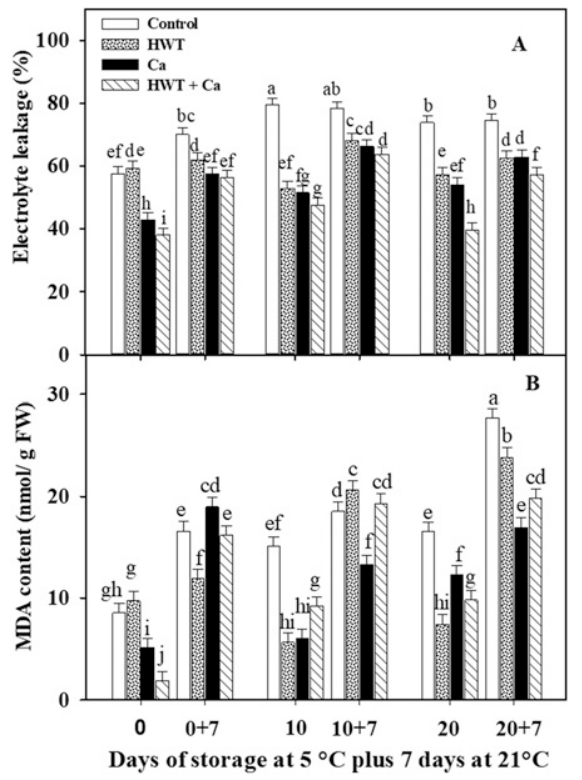

Fig. 2. Electrolyte leakage (\%) (A) and malondialdehyde (MDA) content (B) in mango cv. Keitt after $20 \mathrm{~d}$ of storage at $5{ }^{\circ} \mathrm{C}+7 \mathrm{~d}$ at $21^{\circ} \mathrm{C}$. Data are the mean of five replicates with SD as vertical bars. Different letters show significant differences among treatments $(P<0.05)$ based on the least significant differences (LSD $=4.42$ and 1.85 , respectively) by Fisher's test.

fruit increased. At the end of ripening, the highest carotenoid contents were for $\mathrm{Ca}$ and $\mathrm{HWT}+\mathrm{Ca}$ fruit with values of 9.70 and 


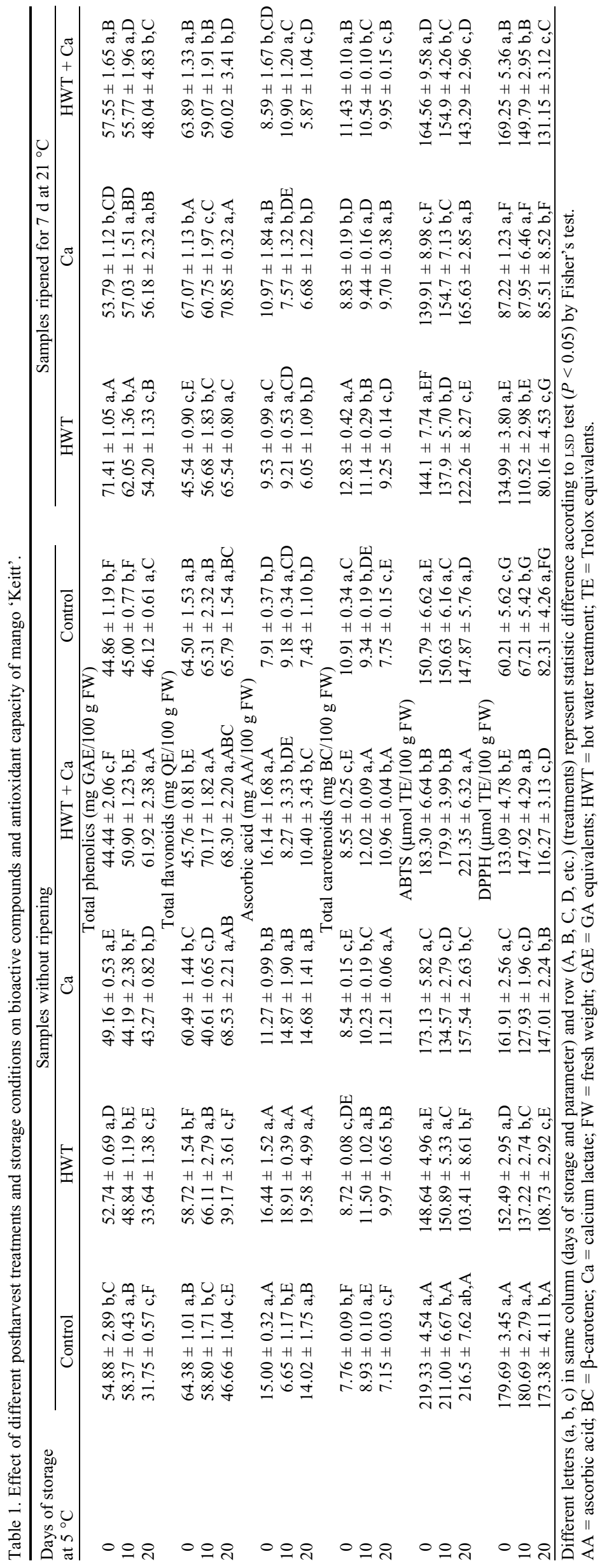

$9.95 \mathrm{mg} \mathrm{BC} / 100 \mathrm{~g} \mathrm{FW}$, respectively $(P<$ $0.05)$.

Antioxidant capacity. The time of cold storage $\left(5^{\circ} \mathrm{C}\right)$ did not affect the ABTS radical scavenging capacity of control mangos (211.00-219.33 $\mu \mathrm{mol}$ TE/100 g FW; $P>$ 0.05 ), but it decreased the scavenging capacity of the HWT and Ca-treated fruit (Table 1). Interestingly, HWT $+\mathrm{Ca}$-treated fruit showed an increase in ABTS antioxidant capacity during cold storage, reaching the highest value after $20 \mathrm{~d}$ at $5{ }^{\circ} \mathrm{C}(221.35 \mu \mathrm{mol}$ $\mathrm{TE} / 100 \mathrm{~g} \mathrm{FW}$ ), which was similar to that registered for control mangos $(216.5 \mu \mathrm{mol}$ TE/100 g FW). The ABTS antioxidant capacity of mango showed positive correlation with TP, flavonoids, carotenoids, and AA (Table 2). Ripening after the removal of cold storage decreased the ABTS antioxidant capacity, except for the Ca-treated fruit that showed an increase (139.91-165.63 $\mu \mathrm{mol}$ TE/100 g FW). The ABTS radical scavenging capacity of the ripened fruit showed positive correlation with TP, total carotenoids, and AA, whereas in the case of total flavonoids this correlation was weaker and in the limit of significance $(r=0.548 ; P=0.065)$ (Table 2).

During cold storage, HWT, $\mathrm{Ca}$, and HWT + Ca decreased the DPPH radical scavenging capacity in $28.7 \%, 21.0 \%$, and $21.4 \%$, respectively, whereas this effect was less pronounced in the control $(4.0 \%)$ (Table 1). The DPPH values of cold-stored mangos showed the strongest positive correlation with TP and total flavonoids, followed by a moderate correlation with total carotenoids and AA (Table 2). Considering the fruit with both cold storage and ripening, the DPPH antioxidant capacity of the HWT $+\mathrm{Ca}$ fruit increased with ripening, but it decreased for all other treated mangos $(P<0.05)$. After fruit ripening and considering the time of cold storage, the DPPH antioxidant capacity of the control mangos was unaffected $(P>0.05)$ but decreased in the HWT and HWT + Ca mangos $(P<0.05)$; nevertheless, at the end of storage, the HWT $+\mathrm{Ca}$ mangos showed the highest DPPH radical scavenging capacity (131.15 umol TE/100 g FW; $P<0.05$ ). Cold-stored and ripened mangos showed DPPH antioxidant values that were strongly correlated with TP and total carotenoids, followed by moderate correlations with total flavonoids and AA (Table 2).

Activity of antioxidant enzymes. The activity of SOD increased significantly in mango fruit stored for $20 \mathrm{~d}$ at $5{ }^{\circ} \mathrm{C}$, showing significant differences $(P<0.05)$ among treatments (Fig. 3A). The highest increments were observed in the hot water-treated fruit, 1.24 times for the HWT $\left(15.01 \mathrm{U} \cdot \mathrm{mg}^{-1}\right.$ of protein) and 1.46 times for the $\mathrm{HWT}+\mathrm{Ca}-$ treated fruit (17.68 U.mg ${ }^{-1}$ of protein). The ripening of fruit not exposed to cold storage affected the SOD activity; HWT $+\mathrm{Ca}$ induced a significant reduction $(P<0.05)$, whereas $\mathrm{Ca}$ treatment induced a large increment (14.39 U.mg $\mathrm{mg}^{-1}$ of protein $)(P<0.05)$. In the case of fruit stored at $5{ }^{\circ} \mathrm{C}$ for $20 \mathrm{~d}$, ripening decreased significantly the SOD activity (3.83-5.33 U.mg ${ }^{-1}$ of protein) and the highest value was observed in the HWT mangos. 
Table 2. Linear correlation coefficients between bioactive compounds and antioxidant capacity.

\begin{tabular}{|c|c|c|c|c|c|c|c|c|}
\hline & \multicolumn{4}{|c|}{ Samples without ripening } & \multicolumn{4}{|c|}{ Samples ripened for $7 \mathrm{~d}$ at $21^{\circ} \mathrm{C}$} \\
\hline & \multicolumn{2}{|c|}{ ABTS } & \multicolumn{2}{|c|}{ DPPH } & \multirow{2}{*}{$\begin{array}{c}\text { ABTS } \\
R\end{array}$} & \multicolumn{3}{|c|}{ DPPH } \\
\hline & $r$ & $P$ & $r$ & $P$ & & $P$ & $r$ & $P$ \\
\hline Total phenolics & 0.844 & 0.001 & 0.928 & 0.00 & 0.803 & 0.002 & 0.913 & 0.00 \\
\hline Total flavonoids & 0.820 & 0.001 & 0.848 & 0.00 & 0.548 & 0.065 & 0.645 & 0.023 \\
\hline Total carotenoids & 0.717 & 0.009 & 0.668 & 0.018 & 0.748 & 0.005 & 0.857 & 0.00 \\
\hline Ascorbic acid & 0.711 & 0.010 & 0.618 & 0.032 & 0.725 & 0.007 & 0.700 & 0.011 \\
\hline
\end{tabular}

$r=$ correlation coefficient of Pearson; $P=$ probability level; ABTS $=2,2^{\prime}$-azino-bis-3-ethylbenzthiazoline6-sulphonic acid; DPPH = 2,2-diphenyl-1-picrylhydrazil.

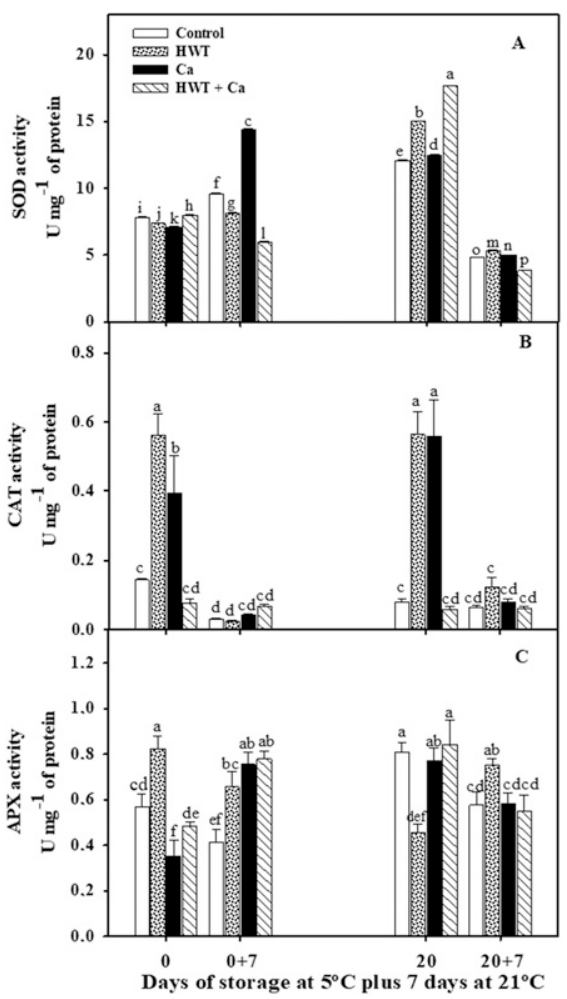

Fig. 3. Antioxidant enzymatic activity of superoxide dismutase (SOD) (A), catalase (CAT) (B), and ascorbate peroxidase (APX) $(\mathbf{C})$ in mango cv. Keitt after 0 and $20 \mathrm{~d}$ of storage at $5^{\circ} \mathrm{C}+7 \mathrm{~d}$ at $21{ }^{\circ} \mathrm{C}$. Data are the mean of six replicates with SD represented by vertical bars. Different letters indicate significant differences among treatments $(P<0.05)$ based on the least significant difference (LSD) (SOD, LSD $=0.08$; $\mathrm{CAT}, \mathrm{LSD}=0.11$; and $\mathrm{APX}, \mathrm{LSD}=0.15$, respectively) by Fisher's test.

Contrasting the effect of cold storage in mango CAT activities, the initial values $(0 \mathrm{~d})$ ranged from 0.07 to $0.56 \mathrm{U} \cdot \mathrm{mg}^{-1}$ of protein, and those of fruit with $20 \mathrm{~d}$ at $5{ }^{\circ} \mathrm{C}$ varied from 0.06 to $0.56 \mathrm{U} \cdot \mathrm{mg}^{-1}$ of protein (Fig. 3B). In both cases, the HWT and Ca-treated mangos shower higher values than the control and HWT + Ca-treated fruit; the main difference is that CAT activity of the Catreated mangos increased after $20 \mathrm{~d}$ of cold storage $\left(0.56 \mathrm{U} \cdot \mathrm{mg}^{-1}\right.$ of protein), whereas that of HWT fruit remained constant $(0.56$ $\mathrm{U} \cdot \mathrm{mg}^{-1}$ of protein $)(P>0.05)$. Ripening significantly decreased the CAT activity, which was more pronounced in fruit without cold storage. The highest CAT activity after $20 \mathrm{~d}$ of cold storage plus $7 \mathrm{~d}$ of ripening was for the HWT mangos (0.12 U. $\mathrm{mg}^{-1}$ of protein), but without significant differences $(P>0.05)$ with respect to the other treatments.

At the beginning of storage $(0 \mathrm{~d})$, the activity of APX increased in response to the HWT and decreased in Ca-treated fruit compared with the control, whereas at $20 \mathrm{~d}$ of cold storage the activity of this enzyme decreased in HWT fruit $(P<0.05)$ and increased in the rest of the treatments $(P<0.05)$ (Fig. 3C). Ripening of fruit non-exposed to cold storage significantly decreased the APX activity of the control and HWT fruit in $27.3 \%$ and $20.5 \%$, respectively, whereas in the case of HWT $+\mathrm{Ca}$ and Ca-treated mangos, this activity increased in $60.6 \%$ and $121.7 \%$, respectively; however, under this storage condition only the control showed significant lower APX activity with respect to the other treatments. On the other hand, ripening of fruit with $20 \mathrm{~d}$ of cold storage increased the APX activity in the HWT mango, whereas the opposite was observed in the other treatments.

The best treatments to induce CI tolerance in mango cv. Keitt were HWT and HWT + $\mathrm{Ca}$. In particular, the HWT $+\mathrm{Ca}$-treated mangos showed the lowest \%EL and MDA content. The better CI tolerance of the HWT + $\mathrm{Ca}$ mangos could be associated with the high activities of antioxidant enzymes and the high content of phenolics, flavonoids, and carotenoids, although, HWT mangos showed high SOD, CAT, and APX activities.

\section{Discussion}

The CI symptoms of mango cv. Keitt were more clearly observed when the cold-stored fruit was transferred to ripening conditions. Compared with the control fruit, HWTs (HWT and HWT + Ca) induced better protection against $\mathrm{CI}$ characterized by lower CII. However, the lowest tissue damage was observed in the HWT + Ca mangos that showed lower EL and MDA content values. Similar results have been reported for mangos 'Zhihua' (Zhu et al., 2003), 'Kent' (Dea et al., 2010), and 'Tommy Atkins' (Almeida Miguel et al., 2016) with HWT. Yimyong et al. (2011) reported less shriveling of the HWT mango 'Okrong' $\left(50^{\circ} \mathrm{C}, 10 \mathrm{~min}\right)$ by the effect of cold storage $\left(8\right.$ and $12{ }^{\circ} \mathrm{C}$ ) and during ripening, reporting changes in metabolic processes that reduced the damage in cell walls, increased the protein stability and the activity of antioxidant enzymes. Up to date, the protective effect of the combination of HWT and $\mathrm{Ca}$ treatments against $\mathrm{CI}$ in mango has not been studied. However, the
$\mathrm{HWT}+\mathrm{CaCl}_{2}$ treatment of lettuce and kiwi resulted in better cold-stress protection than any individual treatment, maintaining cellular integrity and higher unsaturated/saturated fatty acid ratios and decreasing the stress associated with ROS accumulation (MartinDiana et al., 2006; Shahkoomahally and Ramezanian, 2015).

The CI of fruits and vegetables has been associated with oxidation of membrane lipids and an increased membrane permeability (Zhao et al., 2006): phenomena that could explain the reduced EL and MDA production of the HWT, Ca-, and HWT + Ca-treated mangos (Fig. 2). Based on these parameters, the best treatment of mango 'Keitt' against CI was the HWT $+\mathrm{Ca}$. Previous studies have shown that thermal-shock treatment (cold or heat) of different mango cultivars reduced the effect of cold stress, characterized by lower EL and lipid peroxidation (MDA production) (Dea et al., 2010; Nyanjage et al., 1999; Zhao et al., 2006). Dea et al. (2010) and Nyanjage et al. (1999) related this behavior with an increase in the content of soluble solids that led to higher osmotic potential in the membrane and reduction of ion leakage; they also observed that mango fruit with higher calcium content showed lower EL and improved membrane integrity. The calcium ions interact with membrane phospholipids, stabilizing the membrane and maintaining a gradient of protons $\left(\mathrm{Ca}^{2+}, \mathrm{H}^{+}\right)$. Also, calcium interferes with the catalytic activity of lipid enzymes and reduces the overproduction of ROS (Mao et al., 2007). The calcium protective effect of membranes was also observed in cold-stressed fruit such as mangos 'Choke Anan' (Khaliq et al., 2016), 'Tommy Atkins', and 'Kent' (Ngamchuachit et al., 2014); as well as in tomato (Aghdam, 2013) and lemon (Safizadeh et al., 2007).

All postharvest treatments of coldstressed 'Keitt' mango increased the content of phenolics and flavonoids (Table 1), but only the HWT and Ca treatments increased these bioactive compounds during ripening. Aghdam et al. (2015) suggested that HWT produces a moderate stress in the tissue that is associated with the synthesis of antioxidant compounds involved in the neutralization of ROS excess; whereas calcium stabilizes and protects cellular walls and membranes from oxidative stress and reduces the polyphenol oxidase (PPO) activity avoiding the oxidation of phenolic compounds (Leyva-López et al., 2011). Contrasting with our results, the levels of phenolics in 'Choke Anan' and 'Nam Dok Mai' mangos cold stored $\left(4{ }^{\circ} \mathrm{C}\right.$, $30 \mathrm{~d})$ and ripened $\left(27\right.$ to $\left.28{ }^{\circ} \mathrm{C}, 6 \mathrm{~d}\right)$ did not change (Chidtragool et al., 2011); whereas 'Ataulfo' variety stored for $15 \mathrm{~d}$ at $5^{\circ} \mathrm{C}$ showed a minimum reduction (Robles-Sánchez et al., 2009). In this regard, the application of hot water (Talcott et al., 2005) or calcium salts (Khaliq et al., 2016; Zhao et al., 2006) resulted in the accumulation or retention of different compounds during cold storage. Chidtragool et al. (2011) indicated that greater phenolic contents in cold-stored fruit were associated with increased activities of phenylalanine ammonia lyase and PPO, and with inhibition of 
enzymes involved in cell-wall degradation, providing tolerance also to $\mathrm{CI}$.

The highest AA contents in the coldstressed mangos were registered for HWT and Ca-treated fruit. The AA content decreased during ripening for all treatments (Table 1). Contrasting with our results, Djioua et al. (2009) and Zhao et al. (2006) found a retention and reduction of $\mathrm{AA}$ in cold-stored mangos pretreated by cold- and heat treatment, respectively. On the other hand, our results were similar to those registered by Dea et al. (2010) who reported that AA increased in heat-treated mangos; this result was related with higher activity of L-galacto- $\gamma$-lactona dehydrogenase, which is responsible for the synthesis of ascorbate in tissue damaged by thermal stress, as well as with the presence of dehydroascorbic acid included in the quantification. In the present study, the combination HWT and Ca (HWT + Ca) maintained the AA content in 'Keitt' mangos. Calcium lactate could improve the cell-wall firmness by favoring the formation of a larger net of cross-linked pectin; thus, cellular turgor and membrane integrity may be better maintained avoiding the AA oxidation (Abd-Elhady, 2014). Khaliq et al. (2015, 2016) treated mango with $\mathrm{CaCl}_{2}$ and observed less AA reduction during cold stress compared with the combination of $\mathrm{CaCl}_{2}$ with arabic gum. Another study demonstrated that HWT (46.1 $\left.{ }^{\circ} \mathrm{C}, 75-90 \mathrm{~min}\right)$ combined with AAcitric acid- $\mathrm{CaCl}_{2}$ in minimally processed mangos reduces the loss of $\mathrm{AA}$ during cold storage of 'Ataulfo', 'Kent', and 'Keitt' mangos (González-Aguilar et al., 2008).

All postharvest treatments of 'Keitt' mangos increased the total carotenoids, and the highest values at the end of the storage and ripening were registered for the $\mathrm{Ca}$ - and HWT + Ca-treated fruit (Table 1). Similar results were registered for 'Tommy Atkins' mango pretreated with hot water $\left(50{ }^{\circ} \mathrm{C}\right.$, $60 \mathrm{~min}$ ) during cold storage, although this cultivar did not show an increase in total carotenoids during ripening (Talcott et al., 2005). Djioua et al. (2009) observed that HWT $\left(50{ }^{\circ} \mathrm{C}\right.$ for $\left.30 \mathrm{~min}\right)$ of 'Keitt' mango increased its total carotenoids, but the treatment at 46 to $50{ }^{\circ} \mathrm{C}$ for $75 \mathrm{~min}$ caused a reduction in these compounds. It has been proposed that heat treatment promotes cell membrane disruption, chemical extractability, and depending on the time and temperature, oxidation of carotenoids (Djioua et al., 2009). On the other hand, González Aguilar et al. (2008) showed that the combination of HWT + antioxidant solution increased the synthesis of carotenoids in minimally processed mangos during the first days of cold storage, with the highest rate observed during ripening. By contrast, the combination of $\mathrm{HWT}$ and $\mathrm{CaCl}_{2}$ in cold-stored papaya (Ayón-Reyna et al., 2015), carrots, and eggplants (Chepngeno et al., 2016) reduced the BC content.

Mango pulp is rich in bioactive compounds with reducing power and free radical-scavenging capacities (Ma et al., 2011). In our research, the antioxidant capacity of the control fruit was significantly higher than all the treated fruit during the first days of cold storage (Table 1). The increased content of phenolics and flavonoids in the control fruit improved its antioxidant properties. These results agree with previous studies where the antioxidant capacity of different cold-stored mango cultivars was correlated with the polyphenols, flavonoids, carotenoids, and AA contents, providing tolerance to CI (Barman and Asrey, 2014; Chongchatuporn et al., 2013). However, the better balance of bioactive compounds and antioxidant capacity of the coldstored control fruit did not correspond with the CI sensitivity. After ripening, $\mathrm{Ca}$ - and HWT + $\mathrm{Ca}$-treated mangos showed higher antioxidant capacity than the control and HWT fruit. This pattern could be explained by a reduced metabolic activity of heat-treated mangos that showed an impaired synthesis of phenolics and flavonoids (Table 1), limiting their potential for ROS scavenging (Ummarat et al., 2011), whereas the increase for the Ca-treated mangos could be due to higher contents of phenolics and flavonoids. Contrasting with our results, Kim et al. (2007) and Talcott et al. (2005) showed that heat treatment does not affect the polyphenolic content and antioxidant capacity of cold-stored mangos. Khaliq et al. (2016) reported that cold-stored mangos pretreated with a combination of arabic gum$\mathrm{CaCl}_{2}$ showed a $\mathrm{CI}$ reduction, a phenomenon associated with an increased synthesis of phenolic compounds, flavonoids, and vitamins, as well as with a higher antioxidant capacity.

Belhadj et al. (2016) correlated the coldstress sensitivity of mango with both the accumulation of bioactive compounds and the activity of antioxidant enzymes. The coordinated actions of SOD, CAT, and APX, among other antioxidant enzymes, are very important for ROS scavenging, cell membrane protection, and $\mathrm{CI}$ reduction (Wu et al., 2014). Different pretreatments of mango have improved its antioxidant system and cold-stress response (Lopes et al., 2016; Ren et al., 2017; Yimyong et al., 2011). In the present study, HWT + Ca mangos showed increased SOD and APX activities during cold storage, whereas CAT activity was higher in the HWT and Ca-treated fruit. During ripening, SOD and APX activities were higher in HWT mangos, and all-treated mangos showed similar CAT activity (Fig. 3). Thus, the better protection of hot water-treated 'Keitt' mangos (HWT and HWT $+\mathrm{Ca}$ ) against CI seems to be mainly associated with increased activities of SOD and APX. Wang et al. (2008) and Wu et al. (2014) have shown that high activity of fruit antioxidant enzymes decrease the ROS production and CII. Mango fruit with increased SOD, CAT, and peroxidase activities and reduced lipoxygenase and PPO activities showed a reduced concentration of MDA, superoxide anion, and hydroperoxides, as well as higher CI tolerance (Ren et al., 2017). Yimyong et al. (2011) demonstrated that heat treatment increased the CAT activity and CI tolerance of mango; however, the activities and transcription of APX and $\mathrm{Mn}-\mathrm{SOD}$ were reduced. Considering the $\mathrm{Ca}$ treatment, similar results were reported for grafting eggplant seedlings that showed induction of SOD, CAT, and APX activities during cold storage (Gao et al., 2004); the authors suggested that calcium treatment increases the activities of protective enzymes and reduces CI. However, calcium-treated pear fruit showed a reduction in the enzyme activities which resulted higher along with the time, even than the control, and a reduction in their CII (Kou et al., 2015). The effect of the combination HWT $+\mathrm{Ca}$ on the activities of antioxidant enzymes has not been previously reported; thus, this is an important contribution for the fresh market of mango by considering that the HWT and HWT + Ca treatment improves the activities of antioxidant enzymes, mainly SOD and APX, and reduces the CI.

The HWT, alone or combined with calcium lactate treatment $(\mathrm{HWT}+\mathrm{Ca})$, induced CI tolerance of mango fruit cv. Keitt during storage at $5{ }^{\circ} \mathrm{C}$ for up to $20 \mathrm{~d}$ and ripening. The $\mathrm{HWT}+\mathrm{Ca}$ treatment provided CI tolerance, which seems to be associated with lower membrane permeability, highest content of some bioactive antioxidant compounds and the highest activities of SOD and APX during cold storage. Remarkably, the activities of the same two enzymes were higher during ripening of HWT mangos, showing also increased levels of TP and total flavonoids.

\section{Literature Cited}

Abd-Elhady, M. 2014. Effect of citric acid, calcium lactate and low temperature prefreezing treatment on the quality of frozen strawberry. Ann. Agr. Sci. 59:69-75.

Adom, K.K. and H.L. Rui. 2005. Rapid peroxyl radical scavenging capacity (PSC) assay for assessing both hydrophilic and lipophilic antioxidants. J. Agr. Food Chem. 53:6572-6580.

Aghdam, M.S. 2013. Mitigation of postharvest chilling injury in tomato fruit by prohexadione calcium. J. Food Sci. Technol. 50:1029-1033.

Aghdam, M.S., L. Sevillano, F.B. Flores, and S. Bodbodak. 2015. The contribution of biotechnology to improving post-harvest chilling tolerance in fruits and vegetables using heat-shock proteins. J. Agr. Sci. 153:7-24.

Almeida Miguel, A.C., J.F. Durigan, K. Magalhães Marques, C.M. Ascari Morgado, and A. Ferraudo. 2016. Prevention of chilling injury in "Tommy Atkins" mangoes previously stored at $5{ }^{\circ} \mathrm{C}$, using heat treatment and radiation UV (UV-C). Rev. Bras. Frutic. 38:53-63.

Ayón-Reyna, L.E., R. Tamayo-Limón, F. CárdenasTorres, M.E. López-López, G. López-Angulo, H.S. López-Moreno, J. López-Cervántes, J.A López-Valenzuela, and M.O. Vega-García. 2015. Effectiveness of hydrothermal-calcium chloride treatment and chitosan on quality retention and microbial growth during storage of fresh-cut papaya. J. Food Sci. 80:C594-C601.

Barman, K. and R. Asrey. 2014. Salicylic acid pretreatment alleviates chilling injury, preserves bioactive compounds and enhances shelf life of mango fruit during cold storage. J. Sci. Ind. Res. (India) 73:713-718.

Belhadj, F., I. Somrani, N. Aissaoui, C. Messaoud, M. Boussaid, and M.N. Marzouki. 2016. Bioactive compounds contents, antioxidant and antimicrobial activities during ripening of Prunus persica $\mathrm{L}$. varieties from the North West of Tunisia. Food Chem. 204:29-36. 
Brand-Williams, W., M.E. Cuvelier, and C. Berset. 1995. Use of a free radical method to evaluate antioxidant activity. Lebensm. Wiss. Technol. 28:25-30.

Chepngeno, J., W.O. Owino, J. Kinyuru, and N. Nenguwo. 2016. Effect of calcium chloride and hydrocooling on postharvest quality of selected vegetables. J. Food Res. 5:23-40.

Chidtragool, S., S. Ketsa, J. Bowen, I.B. Ferguson, and W.G. Van Doorn. 2011. Chilling injury in mango fruit peel: Cultivar differences are related to the activity of phenylalanine ammonia lyase. Postharvest Biol. Technol. 62:59-63.

Chongchatuporn, U., S. Ketsa, and W.G. Van Doorn. 2013. Chilling injury in mango (Mangifera indica) fruit peel: Relationship with ascorbic acid concentrations and antioxidant enzyme activities. Postharvest Biol. Technol. 86:409-417.

Dea, S., J.K. Brecht, M.C.N. Nunes, and E.A. Baldwin. 2010. Quality of fresh-cut "Kent" mango slices prepared from hot water or non-hot water-treated fruit. Postharvest Biol. Technol. 56:171-180.

Ding, Z.S., S.P. Tian, X.L. Zheng, Z.W. Zhou, and Y. Xu. 2007. Responses of reactive oxygen metabolism and quality in mango fruit to exogenous oxalic acid or salicylic acid under chilling temperature stress. Physiol. Plant. 130:112-121.

Djioua, T., F. Charles, F. Lopez-Lauri, H. Filgueiras, A. Coudret, F.J. Murillo, M.N. Ducamp-Collin, and H. Sallanon. 2009. Improving the storage of minimally processed mangoes (Mangifera indica $\mathrm{L}$.) by hot water treatments. Postharvest Biol. Technol. 52:221-226.

Dürüst, N., D. Sümengen, and Y. Dürüst. 1997. Ascorbic acid and element contents of foods of Trabzon (Turkey). J. Agr. Food Chem. 45:2085-2087.

Food and Agriculture Organization of the United Nations (FAO). 2010. Medium-term prospects for agricultural commodities. Tropical fruit. 16 July 2017. <http://www.fao.org/docrep/007/ y5143s $/ y 5143 \mathrm{~s} 00 . \mathrm{htm}>$.

Food and Agriculture Organization of the United Nations Statistical Database (FAOSTAT). 2017. Crops. 16 July 2017. <http://www.fao.org/ faostat/en/\#data/QC>

Gao, H., G. Chen, L. Han, and H. Lin. 2004. Calcium influence on chilling resistance of grafting eggplant seedlings. J. Plant Nutr. 27:1327-1339.

González-Aguilar, G.A., J. Celis, R.R. SoteloMundo, L.A. de la Rosa, J. Rodrigo-García, and E. Alvarez-Parrilla. 2008. Physiological and biochemical changes of different fresh-cut mango cultivars stored at $5{ }^{\circ} \mathrm{C}$. Intl. J. Food Sci. Technol. 43:91-101.

Hodges, D.M., J.M. DeLong, C.F. Forney, and R.K. Prange. 1999. Improving the thiobarbituric acid-reactive-substances assay for estimating lipid peroxidation in plant tissues containing anthocyanin and other interfering compounds. Planta 207:604-611.

Ketsa, S., S. Chidtragool, and S. Lurie. 2000. Prestorage heat treatment and poststorage quality of mango fruit. HortScience 35:247-249.

Khaliq, G., M.T. Muda Mohamed, A. Ali, P. Ding, and H.M. Ghazali. 2015. Effect of gum arabic coating combined with calcium chloride on physico-chemical and qualitative properties of mango (Mangifera indica L.) fruit during low temperature storage. Scientia Hort. 190:187-194.

Khaliq, G., M.T. Muda Mohamed, H.M. Ghazali, P. Ding, and A. Ali. 2016. Influence of gum arabic coating enriched with calcium chloride on physiological, biochemical and quality responses of mango (Mangifera indica L.) fruit stored under low temperature stress. Postharvest Biol. Technol. 111:362-369.
Kim, Y., J.K. Brecht, and S. Talcott. 2007. Antioxidant phytochemical and fruit quality changes in mango (Mangifera indica L.) following hot water immersion and controlled atmosphere storage. Food Chem. 105:1327-1334.

Kou, X., M. Wu, L. Li, S. Wang, Z. Xue, and B. Liu. 2015. Effects of $\mathrm{CaCl}_{2}$ dipping and pullulan coating on the development of brown spot on "Huangguan" pears during cold storage. Postharvest Biol. Technol. 99:63-72.

Leyva-López, N., J. Bacilio-Heredia, L.A. ContrerasAngulo, M.D. Muy-Rangel, J.P. CamposSauceda, and I. González-Lizarraga. 2011. Sales de calcio mejoran vida de anaquel y aceptabilidad general de papaya (Carica papaya L. var. Maradol) fresca cortada. Rev. Venez. Cienc. Tecnol. Aliment. 2(1):1-15.

Liu, H., W. Jiang, Y. Bi, and Y. Luo. 2005. Postharvest BTH treatment induces resistance of peach (Prunus persica L. cv. Jiubao) fruit to infection by Penicillium expansum and enhances activity of fruit defense mechanisms. Postharvest Biol. Technol. 35:263-269.

Lopes, M.M.A., E.O. Silva, K.M. Canuto, L.M.A. Silva, M.I. Gallao, L. Urban, J.F. AyalaZavala, and M.R.A. Miranda. 2016. Low fluence pulsed light enhanced phytochemical content and antioxidant potential of "Tommy Atkins" mango peel and pulp. Innov. Food Sci. Emerg. Technol. 33:216-224.

Ma, X., H. Wu, L. Liu, Q. Yao, S. Wang, R. Zhan, S. Xing, and Y. Zhou. 2011. Polyphenolic compounds and antioxidant properties in mango fruits. Scientia Hort. 129:102-107.

Malacrida, C., E.M. Valle, and S.B. Boggio. 2006. Postharvest chilling induces oxidative stress response in the dwarf tomato cultivar MicroTom. Physiol. Plant. 127:10-18.

Manganaris, G.A., M. Vasilakakis, G. Diamantidis, and I. Mignani. 2007. The effect of postharvest calcium application on tissue calcium concentration, quality attributes, incidence of flesh browning and cell wall physicochemical aspects of peach fruits. Food Chem. 100:1385-1392.

Mao, L., H. Pang, G. Wang, and C. Zhu. 2007. Phospholipase D and lipoxygenase activity of cucumber fruit in response to chilling stress. Postharvest Biol. Technol. 44(1):42-47.

Martin-Diana, A.B., D. Rico, J.M. Frias, G. Henehan, J. Mulcahy, J. Barat, and C. Barry-Ryan. 2006. Effect of calcium lactate and heat-shock on texture in fresh-cut lettuce during storage. J. Food Eng. 77:1069-1077.

McCollum, T.G., S.D. Aquino, and R.E. McDonald. 1993. Heat treatment inhibits mango chilling injury. HortScience 28:197-198.

Moo-Huchin, V.M., I. Estrada-Mota, R. EstradaLeón, L. Cuevas-Glory, E. Ortiz-Vázquez, M.L. Vargas y Vargas, D. Betancur-Ancona, and E. Sauri-Duch. 2014. Determination of some physicochemical characteristics, bioactive compounds and antioxidant activity of tropical fruits from Yucatan, Mexico. Food Chem. 152:508-515.

Ngamchuachit, P., D.M. Barrett, and E.J. Mitcham. 2014. Effects of 1-methylcyclopropene and hot water quarantine treatment on quality of "Keitt" mangos. J. Food Sci. 79:505-509.

Nyanjage, M.O., H. Wainwright, and C.F.H. Bishop. 1999. Effects of hot-water treatment and storage temperature on electrolyte leakage of mangoes (Mangifera indica Linn.). J. Hort. Sci. Biotechnol. 74:566-572.

Re, R., N. Pellegrini, A. Proteggente, A. Pannala, M. Yang, and C. Rice-Evans. 1999. Antioxidant activity applying an improved ABTS radical cation decolorization assay. Free Radic. Biol. Med. 26:1231-1237.
Ren, Y., J. He, H. Liu, G. Liu, and X. Ren. 2017. Nitric oxide alleviates deterioration and preserves antioxidant properties in 'Tainong' mango fruit during ripening. Hort. Environ. Biotechnol. 58:27-37.

Robles-Sánchez, R.M., M.A. Islas-Osuna, H. Astiazarán-García, F.A. Vázquez-Ortiz, O. Martin-Belloso, S. Gorinstein, and G.A. González-Aguilar. 2009. Quality index, consumer acceptability, bioactive compounds, and antioxidant activity of fresh-cut "Ataulfo" mangoes (Mangifera indica L.) as affected by low-temperature storage. J. Food Sci. 74:S126S134.

Safizadeh, M., M. Rahemi, and M. Aminlari. 2007. Effect of postharvest calcium and hot-water dip treatments on catalase, peroxidase and superoxide dismutase in chilled Lisbon lemon fruit. Intl. J. Agr. Res. 2:440-449.

Secretaría de Agricultura, Ganadería, Desarrollo Rural, Pesca y Alimentación (SAGARPA). 2017Comunicado de prensa. 16 July 2017. $<$ https://www. gob.mx/sagarpa/prensa/aumenta-46-por-cientoexportacion-de-mango-hecho-en-mexico-en2017-105529>.

Shahkoomahally, S. and A. Ramezanian. 2015. Hot water combined with calcium treatment improves physical and physicochemical attributes of kiwifruit (Actinidia deliciosa cv. Hayward) during Storage. HortScience 50:412-415.

Silveira, A.C., E. Aguayo, M. Chisari, and F. Artés. 2011. Calcium salts and heat treatment for quality retention of fresh-cut "Galia" melon. Postharvest Biol. Technol. 62:77-84.

Talcott, S.T., J.P. Moore, A.J. Lounds-Singleton, and S.S. Percival. 2005. Ripening associated phytochemical changes in mangos (Mangifera indica) following thermal quarantine and lowtemperature storage. J. Food Sci. 70:337-341.

Ummarat, N., T.K. Matsumoto, M.M. Wall, and K. Seraypheap. 2011. Changes in antioxidants and fruit quality in hot water-treated "Hom Thong" banana fruit during storage. Scientia Hort. 130:801-807.

U.S. Department of Agriculture (USDA-APHIS). 2014. Treatment schedules. 15 June 2014 $<$ https://www.aphis.usda.gov/aphis/ourfocus/ planthealth/import-information/sa_quarantine_ treatments/ct_quarantine-treatment>.

Vega-García, M.O., G. López-Espinoza, J. ChávezOntiveros, J.J. Caro-Corrales, F. DelgadoVargas, and J.A. López-Valenzuela. 2010. Changes in protein expression associated with chilling injury in tomato fruit. J. Amer. Soc. Hort. Sci. 135:83-89.

Wang, B., J. Wang, H. Liang, J. Yi, J. Zhang, L. Lin, Y. Wu, X. Feng, J. Cao, and W. Jiang. 2008. Reduced chilling injury in mango fruit by $2,4-$ dichlorophenoxyacetic acid and the antioxidant response. Postharvest Biol. Technol. 48:172-181.

Wu, B., Q. Guo, Q. Li, Y. Ha, X. Li, and W. Chen. 2014. Impact of postharvest nitric oxide treatment on antioxidant enzymes and related genes in banana fruit in response to chilling tolerance. Postharvest Biol. Technol. 92:157-163.

Yimyong, S., T.U. Datsenka, A.K. Handa, and K. Seaypheap. 2011. Hot water treatment delays ripening-associated metabolic shift in "Okrong" mango fruit during storage. J. Amer. Soc. Hort. Sci. 136:441-451.

Zhao, Z., W. Jiang, J. Cao, Y. Zhao, and Y. Gu. 2006. Effect of cold-shock treatment on chilling injury in mango (Mangifera indica L. cv. "Wacheng") fruit. J. Sci. Food Agr. 86:2458-2462.

Zhu, S., Z. Ji, W. Lu, and Z. Zhang. 2003. The link between heat-induced polypeptides and chilling tolerance in mangoes (Mangifera indica L.), with evidence from the same fruit partially heated. J. Hort. Sci. Biotechnol. 78:523-527. 